\title{
Association between NAG-B and cadmium in urine with no evidence of a threshold
}

\author{
Alfred Bernard, Nathalie Thielemans, Harry Roels, Robert Lauwerys
}

\begin{abstract}
Objectives-To explore the significance of the increase in urinary excretion of the lysosomal enzyme $\beta$-N-acetylglucosaminidase (NAG) at low exposures to cadmium (Cd) that is frequently found in the absence of any other sign of renal dysfunction.

Methods-The activity was measured of the two main isoenzymes of NAG (NAGA secreted by exocytosis and NAG-B released with cell membranes) in the urine of 49 male workers employed in a $\mathrm{Cd}$ smelter and of 20 age matched controls.

Results-An increased urinary excretion of low molecular weight proteins was noted only in subjects who excreted $>10$ $\mu \mathrm{g} \mathrm{Cd} / \mathrm{g}$ creatinine. The urinary activity of NAG-B showed a dose related increase that was already significant in the group excreting $0 \cdot 5-2 \mu \mathrm{g} \mathrm{Cd} / \mathrm{g}$ creatinine. In multiple regression analysis the NAG-B activity correlated with the excretion of Cd but not with that of lead or mercury. The NAG-A activity was by contrast unaffected by exposure to Cd but correlated with the urinary excretion of lead and copper.

Conclusions-As NAG-B is considered to be the lesional form of NAG, the existence of a specific association between this enzyme and urinary Cd excretion with no detectable threshold suggests that this metal produces cellular alterations at exposures commonly found in the general population.
\end{abstract}

(Occup Environ Med 1995;52:177-180)

Unit of Industrial Toxicology and Occupational Medicine, Catholic University of Louvain Faculty of Medicine, 30.54 Clos Chapelleaux-Champs, B-1200 Brussels, Belgium

A Bernard

N Thielemans

H Roels

R Lauwerys

Correspondence to:

Professor A Bernard, Unit of Industrial Toxicology and Occupational Medicine, Catholic University of Louvain, Faculty of Medcicine, 30.54 Clos Chapelle-aux-Champs, B-1200 Brussels, Belgium.

Accepted 28 October 1994 roups of $\mathrm{CdU}$ thresholds have been identified ${ }^{34}$ : one around $2 \mu \mathrm{g} / \mathrm{g}$ creatinine mainly associated with biochemical alter- ations; a second around $4 \mu \mathrm{g} / \mathrm{g}$ creatinine for the start of high molecular weight proteinuria and some cytotoxic signs (tubular antigens or enzymes), and a third around $10 \mu \mathrm{g} / \mathrm{g}$ creatinine for the development of tubular proteinuria. Effects associated with the $10 \mu \mathrm{g} / \mathrm{g}$ creatinine threshold are known to predict a faster decline of renal function with age. ${ }^{5} \mathrm{By}$ contrast, the relevance of effects that occur at lower thresholds in the pathogenesis of $\mathrm{Cd}$ nephropathy is much less clear. One of the markers presenting interpretative problems is the lysosomal enzyme, $\beta$-N-acetylglucosaminidase (NAG). This enzyme has been shown to be a sensitive indicator of tubular toxicity in several situations that affect the kidneys. ${ }^{6}$ In subjects exposed to $\mathrm{Cd}$ abnormally increased values are detected above a CdU threshold that varies between 4 and $6 \mu \mathrm{g}$ $\mathrm{Cd} / \mathrm{g}$ creatinine. ${ }^{378}$ Several studies, however, have reported that the activity of NAG in urine positively correlates with that of $\mathrm{Cd}$ at unexpectedly low exposures (in some cases $<2 \mu \mathrm{g} / \mathrm{g}$ creatinine).$^{9-13}$ To gain insight into the biological significance of this association we have measured the activity of the two main isoenzymes of NAG-the isoenzyme A excreted in urine by exocytosis (functional form) and the isoenzyme $B$ released into the urine after breakdown of tubular cells (cytotoxic form) $)^{14-16}$ in the urine of $49 \mathrm{Cd}$ smelter workers and 20 control subjects. The relations between these isoenzymes and the urinary concentrations of $\mathrm{Cd}$, lead, and mercury were examined.

\section{Materials and methods \\ SUBJECTS AND EXPOSURE}

The study was conducted on a group of 52 male workers aged 20.8 to 51 years employed in a Cd smelter in Belgium. Their geometric mean (range) urinary excretion of Cd was $2 \cdot 6$ $(0 \cdot 14-52) \mu \mathrm{g} / \mathrm{g}$ creatinine and their mean duration of exposure was seven $(0 \cdot 2-18)$ years. Twenty healthy subjects aged 23.6 to 55.3 years with no occupational exposure to potential nephrotoxins served as controls. Their mean (range) urinary excretion of $\mathrm{Cd}$ was $0.23(0.06-0.77) \mu \mathrm{g} / \mathrm{g}$ creatinine. Three $\mathrm{Cd}$ workers whose urine samples were too dilute (urinary creatinine $<0.03 \mathrm{~g} / 1$ or 2.6 $\mathrm{mmol} / \mathrm{l}$ ) were excluded from the analysis.

\section{METHODS}

All subjects provided a spot urine sample that was immediately divided in two aliquots: one stored without additive at $4^{\circ} \mathrm{C}$ for metals, creatinine, and NAG analysis and the other 
Urinary excretion of heavy metals and proteins in the total population of controls and Cd smelter workers stratified according to the $C d U$ concentration

\begin{tabular}{|c|c|c|c|c|c|}
\hline & \multicolumn{5}{|l|}{$C d U$ ( $\mu g / g$ creatinine $)$} \\
\hline & $\begin{array}{l}<0.5 \\
n=21\end{array}$ & $\begin{array}{l}0 \cdot 5-<2 \\
n=23\end{array}$ & $\begin{array}{l}2-<5 \\
n=8\end{array}$ & $\begin{array}{l}5<10 \\
n=8\end{array}$ & $\begin{array}{l}\geqslant 10 \\
n=9\end{array}$ \\
\hline $\begin{array}{l}\text { Age (y) } \\
\text { Cd† } \\
\text { Lead } \dagger \\
\text { Mercury } \dagger \\
\text { Coppert } \\
\beta_{2}-\text { Microglobulin } \dagger \\
\text { RBP } \dagger \\
a_{1}-\text { Microglobulin } \ddagger \\
\text { Albumin } \ddagger\end{array}$ & $\begin{array}{l}37 \cdot 4(9 \cdot 5) \\
0 \cdot 23(0 \cdot 06-0 \cdot 44) \\
3 \cdot 9(1 \cdot 6-10 \cdot 3) \\
2 \cdot 3(1 \cdot 1-5 \cdot 7) \\
6 \cdot 3(4 \cdot 6-9 \cdot 3) \\
42 \cdot 5(2 \cdot 3-192) \\
52 \cdot 1(18 \cdot 3-132) \\
6 \cdot 4(2 \cdot 0-29 \cdot 6) \\
6 \cdot 6(2 \cdot 5-16 \cdot 8)\end{array}$ & $\begin{array}{c}33 \cdot 6(6 \cdot 9) \\
1.09(0 \cdot 5-1 \cdot 9) \\
5 \cdot 6(1 \cdot 8-14 \cdot 5) \\
2 \cdot 4(1-5 \cdot 3) \\
5 \cdot 8(2 \cdot 7-10 \cdot 8) \\
72(23 \cdot 6-160) \\
54(25-119) \\
9 \cdot 8(2 \cdot 2-47 \cdot 2) \\
6 \cdot 3(2 \cdot 2-31 \cdot 7)\end{array}$ & $\begin{array}{l}38 \cdot 1(9 \cdot 6) \\
3 \cdot 84(2 \cdot 5-4 \cdot 9) \\
6 \cdot 1(2 \cdot 7-44) \\
2 \cdot 3(0 \cdot 7-4 \cdot 3) \\
6 \cdot 6(4 \cdot 3-11 \cdot 6) \\
42(7 \cdot 1-90 \cdot 4) \\
40(25-70) \\
8 \cdot 3(2 \cdot 9-20 \cdot 5) \\
7 \cdot 7(4 \cdot 4-45 \cdot 5)\end{array}$ & $\begin{array}{c}39 \cdot 9(6 \cdot 9) \\
6 \cdot 4(5 \cdot 1-7 \cdot 5) \\
6 \cdot 7(4 \cdot 8-19 \cdot 6) \\
1 \cdot 8(1-3 \cdot 8) \\
8 \cdot 1(6-10 \cdot 7) \\
56 \cdot 8(8 \cdot 2-159) \\
50 \cdot 3(29 \cdot 4-89 \cdot 5) \\
9 \cdot 5(3 \cdot 5-21) \\
6 \cdot 3(4 \cdot 4-8 \cdot 9)\end{array}$ & $\begin{array}{c}34 \cdot 7(7 \cdot 6) \\
26 \cdot 3(10 \cdot 8-52) \\
4 \cdot 8(2 \cdot 3-13 \cdot 7) \\
2 \cdot 8(1 \cdot 4-14 \cdot 6) \\
14 \cdot 1^{\star}(10 \cdot 1-41 \cdot 6) \\
126^{\star}(47 \cdot 6-666) \\
107^{\star}(54-376) \\
20 \cdot 4^{\star}(5 \cdot 2-49 \cdot 5) \\
7 \cdot 6(4 \cdot 9-13 \cdot 2)\end{array}$ \\
\hline
\end{tabular}

Values are geometric with range except for age (mean (SD))

${ }^{\star}$ Significantly different from the group with CdU $<0.5 \mu \mathrm{g} / \mathrm{g}$ creatinine; $\dagger \mu \mathrm{g} / \mathrm{g}$ creatinine; $\ddagger \mathrm{mg} / \mathrm{g}$ creatinine

buffered at $\mathrm{pH} 7$ and stored frozen for the assay of retinol binding protein (RBP), $\beta_{2}-$ microglobulin, $a_{1}$-microglobulin, and albumin. The concentrations of $\mathrm{Cd}$, lead, mercury, and copper in urine were determined by atomic absorption spectrometry (as already described $\left.{ }^{17}\right)$. The activity of total NAG (EC 3.2.1.30) and that of the $B$ isoenzyme were determined by the automated fluorimetric assay of Tucker et al. ${ }^{18}$ The NAG-B isoenzyme was separated from other isoenzymes of NAG - that is, mainly the A and I isoenzymes-after fixation of the NAG-A on an anion exchanger as described by Kritz et al. ${ }^{19}$ The activity of the NAG-A was calculated by subtracting that of NAG-B from the total NAG activity. The concentrations of albumin, $\mathrm{RBP}, \beta_{2}$-microglobulin and $\alpha_{1}$-microglobulin in urine were determined by an automated latex agglutination technique with antibodies from Dakopatts, Glostrup, Denmark and calibrated with standards of purified proteins. ${ }^{20}$

\section{STATISTICAL ANALYSES}

Statistical analyses were done with the Statview SE Graph Software. ${ }^{21}$ All variables

Figure 1 Activity of NAG isoenzymes in the total population of controls and Cd smelter workers as a function of the $C d U$ concentration.

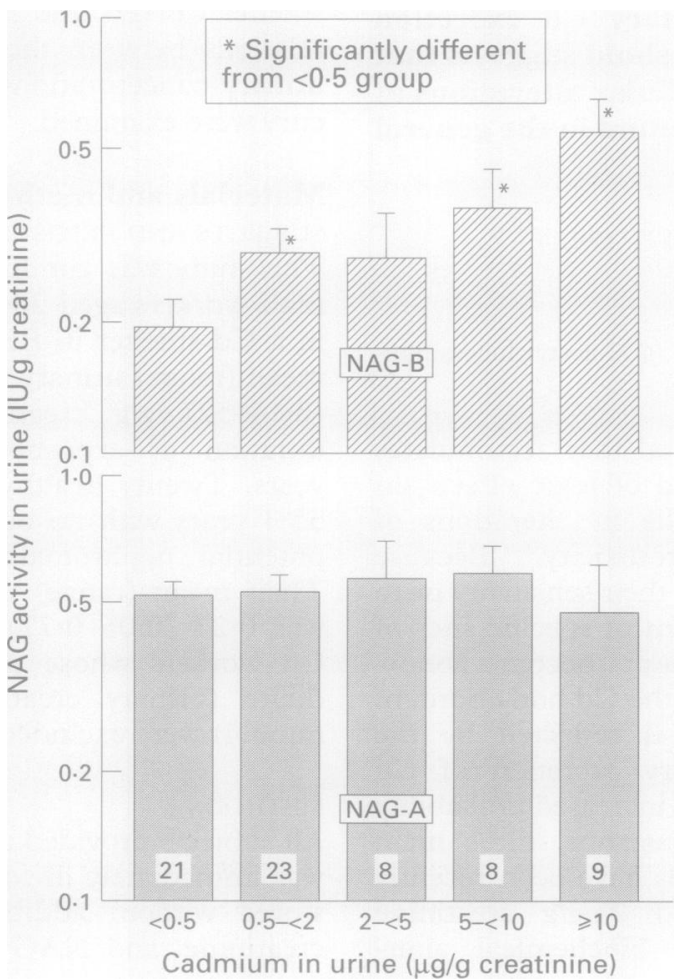

except age were log transformed before statistical analysis and the normality of their distribution was checked with the Kolmogorov-Smirnov one sample test. The results are reported as the geometric mean with, when necessary, the range. Comparisons of the groups stratified according to the urinary $\mathrm{Cd}$ excretion were done by one way analysis of variance (ANOVA) followed by Dunett's multiple comparison test. The associations between the isoenzymes of NAG and the urinary excretion of heavy metals were assessed by stepwise multiple linear regression analysis. The level of significance was set at $P<0.05$.

\section{Results}

As the distributions of CdU of smelter workers and controls greatly overlapped, the two groups were combined and redistributed in five groups of $\mathrm{CdU}(<0.5,0.5-<2,2-<5$, $5-<10$, and $\geqslant 10 \mu \mathrm{g} / \mathrm{g}$ creatinine). The table shows that only the group with $\mathrm{CdU} \geqslant 10$ $\mu \mathrm{g} / \mathrm{g}$ creatinine presented signs of proximal tubular impairment with an increased urinary excretion of $\beta_{2}$-microglobulin, RBP, and $a_{1-}$ microglobulin. This group also excreted more copper. The urinary excretion of NAG-B showed a dose-dependent increase that was already significant in the group with $\mathrm{CdU}$ between 0.5 and $2 \mu \mathrm{g} / \mathrm{g}$ creatinine (fig 1 ). The excretion of NAG-A by contrast was remarkably similar between the five groups with no tendency to rise with CdU. The five subgroups excreted on the average similar amounts of lead, mercury, and albumin.

In the total population, all renal variables with the exception of NAG-A and albumin correlated significantly with $\mathrm{CdU} \quad(\mathbf{P}<$ $0 \cdot 005)$. When the population was restricted to subjects with $\mathrm{CdU}<10 \mu \mathrm{g} / \mathrm{g}$ creatinine, only $\alpha_{1}$-microglobulin and NAG-B were still correlated, and with $\mathrm{CdU}<5 \mu \mathrm{g} / \mathrm{g}$ creatinine, NAG-B was the only marker to maintain a significant association with $\mathrm{CdU}$. In the $<5$ $\mu \mathrm{g} / \mathrm{g}$ creatinine group, which presented no signs of proximal tubular dysfunction, we explored further the relation between $\mathrm{CdU}$ and NAG-B in urine by a stepwise multiple regression analysis with the predictors age and the urinary excretion of $\mathrm{Cd}$, lead, copper, and mercury. Again, CdU remained the only independent variable to be associated with NAGB (partial $r^{2}=0.134$; regression coefficient, $0.2 ; P=0.003)$. This association between 
Figure 2 Correlation between the age adjusted activity of NAG-B and the $C d U$ concentration from 20 control subjects and $24 \mathrm{Cd}$ smelter workers who excreted $<2 \mu \mathrm{g} C d$ creatinine.

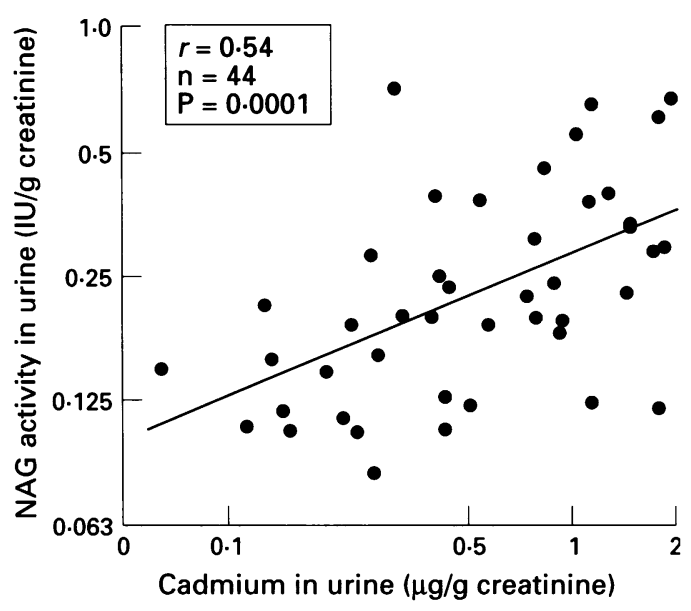

NAG-B and Cd in urine was already apparent in the group with $\mathrm{CdU}$ values $<2 \mu \mathrm{g} / \mathrm{g}$ creatinine and was even stronger (partial $r^{2}=0 \cdot 22$; regression coefficient, $0.31 ; P=0.0001)$. A significant influence of age, independent of $\mathrm{CdU}$, also emerged in this group (partial $r^{2}=0.017$, regression coefficient, $0.013 ; \mathrm{P}=$ 0.002 ). Figure 2 shows the relation between the activity of NAG-B (age adjusted) and $\mathrm{CdU}$ in this group.

Although confirming the lack of influence of $\mathrm{Cd}$ on NAG-A excretion, the multiple regression analysis performed in the group with $\mathrm{CdU}<5 \mu \mathrm{g} / \mathrm{g}$ creatinine showed the existence of positive associations between the urinary activity of NAG-A and age (partial $r^{2}=0.088$; regression coefficient, $0.06 ; \mathrm{P}=$ 0.04 ), the excretion of copper (partial $r^{2}=0.15$; regression coefficient, $0.54 ; \mathrm{P}=$ 0.006 ), and lead (partial $r^{2}=0.064$; regression coefficient, $0.17 ; P=0.045$ ). These associations were also found in the group with CdU $<2 \mu \mathrm{g} / \mathrm{g}$ creatinine.

\section{Discussion}

The diagnosis of $\mathrm{Cd}$ nephrotoxicity relies mainly on the determination of specific plasma proteins, which according to their size reflect the functional integrity of the tubule or glomerulus. ${ }^{1-3}$ The interpretation of these markers in terms of renal dysfunction is relatively straightforward owing to the limited mechanisms that may lead to the increased leakage of plasma proteins into urine (loss of glomerular filter selectivity or failure of tubular reabsorption). ${ }^{22}$ The past decade has witnessed the development of increasingly sensitive indicators that have unravelled the existence of subtle renal changes at exposures to $\mathrm{Cd}$ less than those that give rise to an increased excretion of plasma protein. ${ }^{323}$ These indicators, which consist of various constituents (antigens, enzymes) derived from the kidney, do not unequivocably reflect renal damage or dysfunction. They may be excreted in greater amounts in urine as a result of shedding of damaged tubular cells, of increased cellular turnover associated with tissue regeneration, or else of some metabolic derangements that enhances their renal production or secretion. ${ }^{24}$ For NAG, the existence of distinct isoenzymes may give some clues to interpret its increased excretion. NAG is indeed present in kidney and urine as two major isoenzymes: the isoenzyme A (acidic) which is part of the soluble intralysosomal compartment and secreted in urine by exocytosis; and the isoenzyme B (basic), also intralysosomal, but membrane bound and released in urine linked to disrupted lysosomal membranes. The urinary activity of NAG-A - the predominant form in normal urine-reflects the secretory activity of tubular cells (functional enzymuria) whereas that of NAG-B is an index of the rate of tubular cell breakdown (lesional type enzymuria). ${ }^{14-16}$

Our study shows that $\mathrm{Cd}$ excretion in urine is closely related to that of NAG-B - that is, the lesional form of NAG. The remarkable finding is that this association exists over the whole range of urinary $\mathrm{Cd}$ with no evidence of a threshold. Both variables are already correlated in what is presently considered to be the normal range of CdU for populations exposed only to environmental Cd. To our knowledge our study is the first to report an increased NAG-B excretion in subjects exposed to Cd. Recently, Chia et al have studied the NAG isoenzyme profiles in the urine of workers exposed to lead. ${ }^{25}$ They found a slight increase of NAG-B activity in exposed subjects but no difference in the total NAG activity. No doseeffect or response relation was found between the NAG isoenzymes and the recent or time integrated blood lead concentration. Total NAG and NAG-B activities were significantly higher in subjects with $>25 \%$ increase in blood lead over the past six months. This study, however, did not examine the relations between the NAG isoenzymes in urine and the excretion of lead and more importantly the relation of $\mathrm{Cd}$, which emerges from our analysis as a major determinant.

The relevance of the close association between Cd and NAG-B in urine and its link with the development of Cd tubulopathy (at $\mathrm{CdU}$ thresholds between 4 and $10 \mu \mathrm{g} / \mathrm{g}$ creatinine) is still unknown. A first question to be raised is whether this association is causal or secondary. As NAG-B and Cd in urine both derive from the renal parenchyma, both chemicals might be conceivably linked only through their common associations with a third factor that could be for instance the turn over and exfoliation rate of tubular cells. Subjects in whom these processes would be more active would also excrete both more $\mathrm{Cd}$ and NAG-B. Although this explanation cannot be completely ruled out, especially in subjects with very low exposures, the comparison between $\mathrm{Cd}$ smelter workers and controls nevertheless indicates that $\mathrm{Cd}$ causes an increase of NAG-B activity in urine. This increase is unlikely to result from a higher renal activity of the enzyme as in experimental animals treated with $\mathrm{Cd}$ the total activity of NAG in the renal cortex is unchanged or even slightly decreased. ${ }^{26} \mathrm{~A}$ more likely explanation is suggested by recent in vitro observations on human lymphocytes that showed that $\mathrm{Cd}$ can produce cell damage and death not only by 
necrosis but also by apoptosis (programmed cell death). ${ }^{27}$ The point of interest in these observations is that the apoptotic cell death is inducible by a $\mathrm{Cd}$ dose about 10 -fold lower than that necessary to produce an acute necrotic death. The molecular mechanism by which $\mathrm{Cd}$ can induce apoptosis remains to be elucidated but there are several lines of evidence that suggest that it might be linked to the ability of Cd to raise intracellular free calcium or to mimic calcium in its roles in signal transduction. The apoptotic cell death induced by $\mathrm{Cd}$ can be inhibited by calcium or potassium channel blockers, which suggests that $\mathrm{Cd}$ exerts its toxicity by entering the cell through this route. ${ }^{26}$ Other mechanisms by which Cd could induce apoptosis would be by activating the $\mathrm{Ca}^{2+}$ activated endonucleases either directly by substituting for calcium ${ }^{28}$ (responsible for the early DNA fragmentation that characterises apoptosis) or indirectly through an increase of intracellular free calcium through the inositol pathway. ${ }^{29}$

Necrotic and apoptotic cell deaths are distinct in both their mechanisms and implications. ${ }^{30}$ Necrotic death is the outcome of a cascade of events that lead to major alterations of the cell membrane permeability. As opposed to necrotic death, apoptotic cell death is a process whereby a cell is activated by various signals to undergo a programmed process of self induced death. It is a normal and widespread phenomenon in morphogenesis and cell development processes that necessitate cell deletion. ${ }^{31}$ Fragmentation of genomic DNA is an early and irreversible event that commits the cell to die and that is triggered by $\mathrm{Ca}^{2+}$ activated endonucleases. The relative contributions of apoptotic and necrotic cell deaths in the tubular toxicity of $\mathrm{Cd}$ are largely unknown. One can logically suppose that necrotic cell death is the main mechanism responsible for signs of tubular damage or dysfunction that occur at $\mathrm{CdU}$ thresholds $>4 \mu \mathrm{g} / \mathrm{g}$ creatinine and result in an increased excretion of various constituents (including copper, table) derived from the plasma or kidney. Although its implication in the renal toxicity of $\mathrm{Cd}$ remains to be assessed, cell programmed death seems an attractive explanation for the increased NAG$B$ excretion found at lower concentrations of CdU.

\section{Appendix}

Conversion of units: cadmium $1 \mu \mathrm{g}=8.90$ nmol; lead $1 \mu \mathrm{g}=4.83 \mathrm{nmol}$; mercury $1 \mu \mathrm{g}=4.99 \mathrm{nmol}$; copper $1 \mu \mathrm{g}=15.74 \mathrm{nmol}$; creatinine $1 \mathrm{~g}=8.83 \mathrm{nmol}$.

We gratefully acknowledge $X$ Dumont and $T$ Seminck fo their expert technical assistance. This study was supported by the Fonds de la Recherche Scientifique Médicale (Belgium), the Commission of the European Communities, and the Federal Services of the Scientific, Technical, and Cultural Affairs of the Prime Minister's Service (Belgium). A M B is Research Director of the Fonds de la Recherche Scientifique Médicale.

1 Kjellström T. Renal effects. In: Friberg L, Elinder GC, Kjellström T, Nordberg GF, eds. Cadmium and health: toxicological and epidemiological appraisal. Vol 2. Effects and response. Boca Raton, Florida: CRC Press, 1986:21-109.

2 Bernard A, Lauwerys R. Effects of cadmium in humans. In: Foulkes EC, ed. Handbook of experimental pharma- cology. Vol 80. Berlin: Springer Verlag, 1986:135-77.

3 Roels H, Bernard A, Cardenas A, Buchet JP, Lauwerys R Hotter $\mathrm{G}$, et al. Markers of early renal changes induced by industrial pollutants. III Application to workers exposed to cadmium. Br $\mathcal{F}$ Ind Med 1993;50:37-48.

4 Bernard A, Roels H, Buchet JP, Lauwerys R. Cadmium and health: the Belgian experience. In: Nordberg GF, Herber RFM, Alessio L, eds. Cadmium in the human environment: toxicity and carcinogenicity. Lyon: IARC 1992:15-33. IARC Sci Publ No 118.

5 Roels H, Lauwerys R, Buchet JP, Bernard AM, Vos A, Overstyns $M$. Health significance of cadmium-induced renal dysfunction: a five year follow-up. $B r \mathcal{F}$ Ind Med renal dysfunction:

6 Price RG. Measurement of $\mathrm{N}$-acetyl- $\beta$ - $\mathrm{D}$-glucosaminidase and its isoenzymes in urine methods and clinical applications. Eur f Clin Chem Clin Biochem 1992;30:693-705.

7 Verschoor M, Herber R, van Hemmen J, Wobowo A, Zielhuis R. Renal function of workers with low-level cadmium exposure. Scand $\mathcal{f}$ Work Environ Health 1987; 13:232-8.

8 Mueller PW, Smith JS, Steinberg KK, Thun MJ. Chronic renal tubular effects in relation to urine cadmium levels. Nephron 1989;52:45-54.

9 Kawada T, Koyama H, Suzuki T. Cadmium, NAG activity, and $\beta_{2}$-microglobulin in the urine of cadmium pigment and $\beta_{2}$-microglobulin in the urine of
workers. $B r \mathcal{I}$ Ind Med 1989;46:52-5.

10 Kawada T, Tohyama H, Suzuki S. Significance of the excretion of urinary proteins for a low level of occupaexcretion of urinary proteins for a low level of occupational exposure to cadm

11 Chia KS, Ong CN, Endo G. Renal tubular function of workers exposed to low levels of occupational exposure to cadmium. Int Arch Occup Environ Health 1990;62 95-100.

12 Bernard A, Roels $H$, Thielemans N, Van Lierde $M$ Lauwerys R. Assessment of the causality of the cadmium-protein relationship in the urine of the general population with reference to the Cadmibel study. In population with refere the human environment: toxicity and carcinogenicity. Lyon: the human environment: toxicity and carcinogenicity

13 Cardenas A, Roels H, Bernard A, Barbon R, Buchet JP, Lauwerys $\mathrm{R}$, et al. Markers of early renal changes induced by industrial pollutants. III Application to workers exposed to lead. $B r \mathcal{F}$ Ind Med 1993;50 28-36.

14 Tucker SM, Pierce RJ, Price RG. Characterization of human $\mathrm{N}$-acetyl- $\beta$-D-glucosaminidase isoenzymes as an indicator of tissue damage in disease. Clin Chim Acta 1980;102:29-40.

15 Whiting PH, Petersen J, Power DA, Stewart DM, Catto GRD, Adward N. Diagnostic value of urinary N-acetylD-glucosaminidase, its isoenzymes and the fractional excretion of sodium following renal transplantation. Clin Chim Acta 1983;130:369-76.

16 Bernard A, Lauwerys R. Cadmium, NAG activity and $\beta$. microglobulin in the urine of cadmium pigment workers. microglobulin in the urine

17 Roels H, Lauwerys R, Konings J, Buchet JP, Bernard A Green $S$, et al. Renal function and hyperfiltration capacity in lead smelter workers with high bone lead. Occup Environ Med 1994;51:505-12.

18 Tucker S, Boyd PJR, Thompson AE, Price RG Automated assay of $\mathrm{N}$-acetyl-glucosaminidase in norma and pathological human urine. Clin Chim Acta 1975;62 333-9.

19 Kritz W, Samaan GJ, Leberre C, Demelier JF, Biou D. Semi-automated fluorimetric assay for total and B Nacetyl- $\beta$-D-glucosaminidase: analytical investigation. f Clin Lab Analysis 1991;5:1-2.

20 Bernard A, Lauwerys R. Continuous flow system for the automation of latex immunoassay by particle counting. automation of latex immun

21 Fedman, Gagnon J, Hofman R, Simpson J. Abacus Concepts. 1988.

22 Bernard A, Lauwerys R. Proteinuria: mechanisms and changes in toxic nephropathies. Crit Rev Toxicol 1991 21:373-405.

23 Lauwerys R, Bernard A, Roels H, Buchet JP. Cadmium exposure markers as predictors of nephrotoxic effects. Clin Chem 1994;40:1391-4.

24 Lauwerys R, Bernard A. Early detection of the nephrotoxic effects of industrial chemicals: state of the art and future prospects. Am F Ind Med 1987;11:275-85.

25 Chia KS, Mutti A, Tan C, Ong HY, Jeyaeatman J, Ong NC, Lee E. Urinary N-acetyl- $\beta$-D-glucosaminidase activity in workers exposed to inorganic lead. Occup activity in workers exposed
Environ Med 1994;51:125-9.

26 Cardenas A, Bernard A, Lauwerys R. Disturbance of sialic acid metabolism by chronic cadmium exposure and its acid metabolism by chronic cadmium exposure and its relation

27 El Azzouzi B, Tsangaris GTh, Pellegrini O, Manuel Y Benveniste J, Thomas Y. Cadmium induces apoptosis in a human T cell line. Toxicology 1994;88:127-39.

28 Lohmann RD, Beyersmann D. Cadmium and zinc mediated changes of the $\mathrm{Ca}^{2+}$-dependent endonuclease in apoptosis. Biochem Biophys Res Commun 1993;190: 1097-103.

29 Smith JB, Dwyer SD, Smith L. Cadmium evokes inosito polyphosphate formation and calcium mobilization f Biol Chem 1989;264:7115-8.

30 Isaacs $\mathrm{T}$. Role of programmed cell death in carcinogenesis. Environ Health Perspect 1993;101(suppl 5):27-64.

31 Wyllie AH, Kerr JFR, Currie AR. Cell death: the significance of apoptosis. Int Rev Cytol 1980;68:252-306. 